tive effect of oral oestrogens and show an apparent increase in bone mass after treatment with subcutaneous oestradiol and testosterone.

We thank Birthright for its financial support, which made this work possible, and D Cooper and D Lowe, of the computer unit, King's College School of Medicine and Dentistry, for their help with the statistical analysis.

1 Albright F, Smith PH, Richardson AM. Postmenopausal osteoporosis; its clinical features. 7 AMA 1941;116:2465-74

2 Lindsay R, Aitken JM, Anderson JB, Hart DM, MacDonald EB, Clarke AC. Long term prevention of postmenopausal osteoporosis by oestrogen. Lancet 1976;i:1038-41

3 Nachtigall LE, Nachtigall RH, Nachtigall RD, Beckman EM. Estrogen replacement therapy: a ten year prospective study in the relationship to osteoporosis. Obstet Gynecol 1979;53:277-81.

4 Christiansen C, Christiansen MS, Transbol I. Bone mass in postmenopausal women after withdrawal of oestrogen/gestagen replacement therapy. Lancet 1981;i:459-61.

5 Studd JWW, Anderson HM, Montgomery JC. Hormonal treatment, selection of patients-kind and duration of treatment. In: Greenblatt RB, de Gruyter of patients-kind and duration of treatment. In: Greenblatt RB, de Gruyter
W, eds. A modern approach to the menopause. Berlin: de Gruvter, 1986: W, eds

6 Thom M, Studd JWW. Procedures in practice: hormone implantation. $\mathrm{Br}$ Med F 1980; : $648-50$.

7 Studd JWW, Magos AL. Hormone pellet implantation for the menopause and premenstrual tension. Obstet Gynecol Clin North Am 1987;14:229-49.

Studd JWW, Thom M. Oestrogens and endometrial carcinoma. In: Studd JWW, ed. Progress in obstetrics and gunaecologv. Vol 1. London: Churchill Livingstone, 1981:182-98

9 Neilsen SP, Krolner BL. Photon-beam absorptiometry. In: Dixan ASJ, Russell RGG, Stamp TCB, eds. Osteoporosis-a multidisciplinary problem. Sumposium No 55, International Congress of the Royal Society of Medicine. London: Academic Press, 1983:105-8.

10 Murby B, Fogelman I. Bone mineral measurements in clinical practice. $\mathrm{Br}$. Hosp. Med 1987;37:453-8.
11 Barlow EH, Abdulla HI, Roberts ADG, Al Azzawi F, Leggate I, Hart DM Long term hormone implant therapy-hormonal and clinical effects. Obste Gynecol 1986;67:321-5

12 Lindsay R, Hart DM, Clark DM. The minimum effective dose of estrogen for the prevention of post-menopausal bone loss. Obstet Gynecol 1984;63:759.

13 Powers MS, Schenkel L, Darey PE, Good WR, Balestra JC, Place VA. Pharmacokinetics and pharmacodynamics of transdermal forms of 17 estradiol: comparison with conventional oral estrogens used for hormone replacement. Am f Obstet Gynecol 1985;152:1099-106.

14 Chetkowski RJ, Meldrum DR, Steingold KA, et al. Biologic effects of transdermal estradiol. N Engl I Med 1986;314:1615-20.
the

15 Cardozo LD, Gibb DMF, Studd JWW, Tuck SM, Thom MH, Cooper DJ. The use of hormone implants for climacteric symptoms. Am 7 Obstet Gynecol 1984;148:336-7.

16 Ravnikar VA. Compliance with hormone therapy. Am 7 Obstet Gynecol $1987 ; 15: 1332-4$

17 Studd JWW, Dubiel M, Kakkar VV, Thom M, White PJ. The effects of hormone replacement therapy on glucose tolerance, clotting factors, fibrinolysis and platelet behaviour in post-menopausal women. In: Cooke ID, ed. The role of oestrogen/progestogen in the management of the menopause. Lancaster: MTP Press, 1978:41-59.

18 Thom M, Collins WP, Studd JWW. Hormonal profiles in postmenopausal women after therapy with subcutaneous implants. Br $\mathcal{F}$ Obstel Gynaecol $1981 ; 88: 426-33$

19 Smith R. Osteoporosis: cause and management. Br Med f 1987;294:329-32.

20 Keil DP, Felson DT, Anderson JJ, Wilson DWF, Moskowitz MA. Hip fractures and the use of estrogens in postmenopausal women. $N$ Engl f Med 1987;317:1169-74

21 Brincat M, Moniz CF, Studd JWW, et al. The long term effects of the menopause and of administration of sex hormones. Br 7 Obstet Gynaecol 1985;92:256-9.

22 Brincat M, Versi E, Moniz CF, Magos A, De Trafford J, Studd JWW. Skin collagen changes in post-menopausal women receiving different regimes of estrogen therapy. Obstet Gynecol 1987;70:123.

23 Savvas M, Brincat M, Studd JWW. Postmenopausal osteoporosis. Br f Hosp Med 1987;38:16.

24 Birkenhager-Frenkel DH. A significant lack of collagen in osteoporotic bone. In: Christiansen C, Johansen JS, Riis BJ, eds. Proceedings of the international symposium on osteoporosis. Copenhagen: Osteopress Aps, 1987:443-5.

(Accepted 12 April 1988)

\title{
Reversal of renal failure in nephritis associated with antibody to glomerular basement membrane
}

\section{A P Maxwell, W E Nelson, Claire M Hill}

Renal Unit, Belfast City Hospital, Belfast BT9 7AB A P Maxwell, MRCP, registrar

W E Nelson, MRCP, consultant nephrologist

Institute of Pathology, The Queen's University of Belfast, Belfast BT12 6BA Claire M Hill, MRCPATH, senior lecturer

Correspondence to: Dr Nelson.
Nephritis associated with antibody to glomerular basement membrane generally presents as rapidly progressive renal failure. Histological examination shows crescentic nephritis with linear deposits of IgG on the glomerular basement membrane. Pulmonary haemorrhage may occur. Effective treatment comprises immunosuppression and plasma exchange.' Recovery of useful renal function is considered to be unlikely but has been reported in patients dependent on dialysis. ${ }^{2}$ We describe such a case in a patient with acute oliguric renal failure.

\section{Case report}

A 35 year old woman was referred in March 1987 with a one month history of tiredness and nausea. She complained of haematuria and oliguria but did not have any respiratory symptoms. She had a history of essential hypertension, which had been treated with a thiazide diuretic. Her renal function had been normal eight months earlier. On examination her blood pressure was normal and she did not have a rash. Radiographic examination of her chest showed no abnormalities. Her haemoglobin concentration was $101 \mathrm{~g} / \mathrm{l}$, urine volume $0.4 \mathrm{l}$, serum creatinine concentration $435 \mu \mathrm{mol} / 1$, and creatinine clearance $12 \mathrm{ml} /$ minute. Her urine showed haematuria and red cell casts on microscopy.

Two days later her renal function had deteriorated further (serum creatinine concentration $715 \mu \mathrm{mol} / \mathrm{l}$ and creatinine clearance $2 \mathrm{ml} /$ minute). She underwent haemodialysis, after which percutaneous renal biopsy was performed. On histological examination two of the four glomeruli obtained showed florid necrotising crescentic glomerulonephritis; there was an inflammatory reaction around the glomeruli and associated tubulointerstitial tissue. The other two glomeruli showed mild mesangial hypercellularity. No arteriolar lesions were observed. Immunofluorescence showed strongly positive linear deposits of $\mathrm{IgG}$ along the surviving capillary walls of the glomeruli. Her serum contained a high titre ( $80 \%)$ of antibody to glomerular basement membrane (normal value $<12 \%$ ) and a transient low titre of antibody to the cytoplasm of neutrophils on radioimmunoassay.

Treatment with $3 \mathrm{mg}$ cyclophosphamide $/ \mathrm{kg}, 60 \mathrm{mg}$ prednisolone, and daily plasma exchange (4 litres) was started. The titre of antibody to glomerular basement membrane decreased to normal values (figure). She

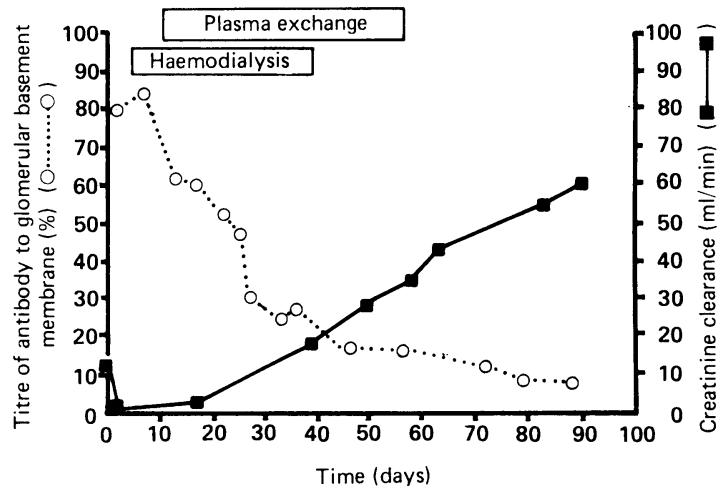

Changes in titre of antibody to glomerular basement membrane and creatinine clearance during treatment with plasma exchange and cyclophosphamide and prednisolone

remained dependent on dialysis for four weeks; subsequently her renal function gradually recovered almost to normal (serum creatinine concentration $140 \mu \mathrm{mol} / 1$ and creatinine clearance $60 \mathrm{ml} /$ minute). Plasma exchange was stopped after six weeks and cyclophosphamide after eight weeks. Ten months after 
presentation she remained well and did not require further immunosuppression.

\section{Comment}

We believe that this case shows that nephritis associated with antibody to glomerular basement membrane, which rapidly leads to the patient becoming dependent on dialysis, may be reversible if early diagnosis and treatment are possible. Because of the few glomeruli in the biopsy specimen assessment of the extent and severity of the disease was difficult. The presence of some fairly normal glomeruli and the short history of rapidly progressive renal failure suggested that treatment might be effective. The assay for determining circulating antibodies to glomerular basement membranes was invaluable in monitoring the activity of the disease and encouraged us to persist with treatment as the antibody titres declined. The presence of antibody to the cytoplasm of neutrophils initially is interesting, but its importance in this patient is unclear. It has been reported as being of diagnostic value in Wegener's granulomatosis and microscopic polyarteritis. ${ }^{3}$ Our patient did not have features of vasculitis. The basic histological diagnosis was crescentic nephritis due to antibody to glomerular basement membranes.
The poor prognosis of patients with this condition, which is associated with renal failure necessitating dialysis, has led to doctors being reluctant to undertake or persist with prolonged immunosuppression and plasma exchange. ${ }^{+5} \mathrm{We}$ suggest that patients with renal impairment of recent onset and with some viable glomeruli on histological examination may regain renal function despite having needed dialysis for several weeks.

We thank Dr C M Lockwood, Renal Laboratory, Hammersmith Hospital, London, for the radioimmunoassays.

1 Pusey CD, Lockwood CM, Peters DK. Plasma exchange and immunosuppressive drugs in the treatment of glomerulonephritis due to antibodies to the lomerular basement membrane. Int $\mathcal{F}$ Artif Organs 1983;6:15-8.

2 Fort J, Espinel E, Rogriquez JA, Curull V, Madrenas J, Piera L. Partia recovery of renal function in an oligoanuric patient affected with Goodpasture's syndrome after treatment with steroids, immunosuppressives and plasmapheresis. Clin Nephrol 1984;22:211-2.

3 Savage COS, Winearls CG, Jones S, Marshall PD, Lockwood CM. Prospective study of radioimmunoassay for antibodies against neutrophil cytoplasm in diagnosis of systemic vasculitis. Lancet 1987; ;: 1389-93.

4 Flores JC, Taube D, Savage COS, et al Clinical and immunological evolution of ligonuric ant Sa Savage COS, Pusc CD, Bowm C, Rees AJ, Lockwood CM A iglo; 5-8. bac BrMed f 1986:292:3014.

Accepted 9 March 1988
Indian Council of Medical

Research, Centre of

Advanced Research in

Virology, Vellore,

Tamilnadu 632 004, India

Vaskar Saha, DCH,

demonstrator

T Jacob John, PHD, professor of virology

S Dhamodaran, MSC,

research fellow

\section{Department of Clinical}

Pathology and Blood Bank,

Christian Medical College

Hospital, Vellore,

Tamilnadu

Robert H Carman, MD,

professor of clinical pathology

Correspondence to: $\mathrm{Dr}$ John.

\section{Highly sensitive screening tests for hepatitis B surface antigen in transfusion centres of developing countries}

\author{
Vaskar Saha, T Jacob John, S Dhamodaran, \\ Robert H Carman
}

Although routine screening of donor blood for hepatitis B surface antigen ( $\mathrm{HBsAg})$ is desirable in our region, which has a moderately high prevalence of carriers,' screening is reported not to be cost effective in west Africa.' Therefore we assessed the risks, costs, and benefits when blood from donors was not screened or was screened with tests of low, medium, and high sensitivity. We avoided giving transfusions of infectious blood but calculated the risk of infection from the prevalence of carriers of $\mathrm{HBsAg}$ in the donor population and of susceptibility to infection among potential recipients.

\section{Methods and results}

Serum from 500 consecutive volunteer blood donors was screened for HBsAg by counterimmunoelectrophoresis, ${ }^{3}$ reverse passive haemagglutination with commercial kits, and enzyme linked immunosorbent assay (ELISA) (Auszyme monoclonal, Abbott, Chicago). Serum from 500 consecutive patients who were cross matched for transfusion was screened sequentially for
HBsAg, antibody to hepatitis B core antigen (Corzyme, Abbott), and antibody to HBsAg (Ausab, Abbott). All serum samples positive on ELISA were retested to confirm the result.

Four $(0.8 \%)$ of the donors were positive for $\mathrm{HBsAg}$ on counterimmunoelectrophoresis; $12(2.4 \%)$ yielded positive results on reverse passive haemagglutination screening, $11(2 \cdot 2 \%)$ of which were confirmed by reverse passive haemagglutination blocking tests; and $35(7 \%)$ yielded positive results on ELISA (table). All samples of serum positive on counterimmunoelectrophoresis were positive on reverse passive haemagglutination, and all samples positive on reverse passive haemagglutination were positive on ELISA. The sensitivities of counterimmunoelectrophoresis and reverse passive haemagglutination were only $11 \%$ and $31 \%$, but their specificities were $100 \%$ and $99 \%$, respectively.

Among the 500 potential recipients of transfusions 99,108 , and 39 were positive for $\mathrm{HBsAg}$, antibody to hepatitis B core antigen, and antibody to $\mathrm{HBsAg}$, respectively; $254(50 \cdot 8 \%)$ did not have any markers of the virus and were thus susceptible to infection. Without screening, the probability of one unit of infectious blood being given to a susceptible individual was $0.036(50.8 \% \times 7 \%)$. With routine screening by counterimmunoelectrophoresis the risk of infection from a three unit transfusion reduced from 0.108 $(0.036 \times 3)$ to $0.0945(50.8 \% \times 6.2 \% \times 3)$. Routine screening with reverse passive haemagglutination decreased the risk to $0.073(50 \cdot 8 \% \times 4.8 \% \times 3)$.

Counterimmunoelectrophoresis, reverse passive haemagglutination, and ELISA cost US $\$ 0.50, \$ 1.00$,

Risks of transfusing blood positive for hepatitis $B$ surface antigen $(H B s A g)$ with different screening tests

\begin{tabular}{|c|c|c|c|c|c|c|}
\hline \multirow[b]{2}{*}{ Screening test } & \multirow{2}{*}{$\begin{array}{c}\% \text { Of units } \\
\text { positive for } \\
\text { HBsAg detected }\end{array}$} & \multirow{2}{*}{$\begin{array}{l}\% \text { Of units } \\
\text { positive for } \\
\text { HBsAg } \\
\text { not detected }\end{array}$} & \multicolumn{3}{|c|}{$\begin{array}{l}\text { Risk of an uninfected recipient } \\
\text { receiving } \mathrm{HBsAg} \text { if he or she receives: }\end{array}$} & \multirow{2}{*}{$\begin{array}{l}\% \text { Of transfusions } \\
\quad \text { of } 3 \text { units) } \\
\text { in which infection } \\
\text { averted by screeningt }\end{array}$} \\
\hline & & & 1 Unit & 2 Units & 3 Units & \\
\hline None & 0 & $7 \cdot 0$ & 0.036 & 0.072 & $0 \cdot 108$ & 0 \\
\hline Counterimmunoelectrophoresis & $0 \cdot 8$ & $6 \cdot 2$ & 0.031 & $0 \cdot 063$ & 0.094 & $1 \cdot 4$ \\
\hline Reverse passive haemagglutination & $2 \cdot 2$ & 4.8 & 0.024 & $0 \cdot 049$ & 0.073 & $3 \cdot 5$ \\
\hline Enzyme linked immunosorbent assay (ELISA) & $7 \cdot 0$ & 0 & 0 & 0 & 0 & $10 \cdot 8$ \\
\hline
\end{tabular}

Percentage detected by ELISA minus percentage detected by other method.

$t$ (Risk associated with unscreened blood minus risk associated with given method $) \times 100$. 